\title{
Mamuratü’I-Aziz Vilayeti Yabancı Misyonu: Kapusenler (Capucins)
}

\author{
Mission in Mamuratu'I-Aziz Province: Capucins
}

\section{Selim Kılıçoğlu* (i)}

\section{Öz}

Misyonerlik faaliyetleri Osmanlı topraklarında 16. yüzyıldan beri etkin bir şekilde devam etmiştir. Osmanlı toprakları içerisinde yer alan ve misyoner raporlarında "Bible Land" olarak tanımlanan Anadolu coğrafyası ise misyon çalışmalarının önemli bölgelerindendir. Günümüzde Anadolu coğrafyası içerisinde yer alan ve ağırlıklı olarak Elazığ il sınırlarını kapsayan Mamuratü’l-Aziz Vilayeti, 19. yüzyılda misyonerliğin merkez istasyonları arasındadır.

Bu çalışmanın temel amacı, Osmanlı topraklarında yürütülen misyon faaliyetlerinden Fransız misyonuna, özelde de Anadolu'daki faaliyet alanlarına dikkat çekmek ve tartışma sahası oluşturmaktır. Üç ana bölüme ayrılan bu makalede, misyonerliğin Osmanlı topraklarındaki genel şeması, Fransızların bu genel şema içerisindeki konumu ve Anadolu coğrafyası özelinde bulunan Mamuratü’l-Aziz ve Harput'un yeri incelenmektedir. Çalışmada Osmanlı arşiv belgelerinden elde edilmiş çizimlerle o dönemde gezginler tarafından çekilmiş görsellerden yararlanılmıştır. Bu bölgede Fransisken cemaatine bağlı olan Kapusen tarikatı, Fransa Devleti himayesinde kolej seviyesinde yapı inşa edip çalışmalar yürütmüşlerdir. Makale kapsamında Harput ve Mamuratü'l Aziz'de Kapusenlerin yapmış oldukları inşa faaliyetleri de değerlendirilmiştir.

\section{Anahtar Kelimeler}

Kapusen, Mamuratü'I-Aziz, Harput, Fransa Koleji, Anadolu

\begin{abstract}
Missionary activities have been active in the Ottoman lands since the $16^{\text {th }}$ century. The Anatolian geography, which is located in the Ottoman lands and defined as the "Bible Land" in missionary reports, is one of the important areas of mission work. Mamuratü'l-Aziz Province, which is located in the Anatolian geography today and includes the provincial borders of Elazig, is among the central stations of missionary in the $19^{\text {th }}$ century.

The main purpose of this study is to draw attention to the French mission in the mission works carried out in the Ottoman lands, and to the activity and working areas in Anatolia in particular, and to create a discussion area. In this study, which I have divided into three main sections, the general scheme of Missionary in the Ottoman lands consists of the position of the French in this general scheme and the location of Mamuratü'l-Aziz and Harpoot in the Anatolian geography. In the study, drawings obtained from Ottoman archive documents and images taken by the traveler or their travelers in the period were used. In this region, the Capuchins, which is affiliated with the Franciscan community, built and carried out studies at the college level under the auspices of the French State. Within the scope of the article, the construction activities carried out by the Capuchins in Harpoot and Mamuratü'l Aziz were evaluated.
\end{abstract}

\section{Keywords}

Capucins, Mamuratü'l-Aziz, Harpout, France College, Anatolia

* Sorumlu Yazar: Selim Kılıçoğlu (Arş. Gör.), Fırat Üniversitesi, Mimarlık Fakültesi, Mimarlık Bölümü, Elazığ, Türkiye. E-posta: selim.kilicoglu@gmail.com ORCID: 0000-0003-4173-9779

Atıf: Kilicoglu, Selim. “Mamuratü’l-Aziz Vilayeti Yabancı Misyonu: Kapusenler (Capucins).” Art-Sanat, 17(2022): $253-273$. https://doi.org/10.26650/artsanat.2022.17.930361 


\section{Extended Summary}

There are three main sections that stand out in this article. The first is the activities of the Christian missionary, the second is the mission work carried out by the French in the Ottoman Empire, and the other is the construction activities in Mamuratü'l Aziz, an important mission station in Anatolia. The main purpose of the study is to draw attention to the mission works carried out in Anatolia under the French auspices and to create a field of discussion.

As it is known, missionary dates back to the first times of Christianity. The teachings of St. Paul, which come to mind when missionary is mentioned, constitute the main reference point in the field of missionary work. Thus, Christianity was tried to be conveyed to people in other geographies, it was aimed to adopt and accept religion.

Anatolia, which has an important place in Christian teachings and history and known as Bible land, has been considered among the important focal points of missionary. The subjects of the Ottoman Empire, which have ruled in these lands for a long time, have been the first addressees of the missionary. The first known missionary activity in the Ottoman Empire started in 1583 when the Jesuits came to Istanbul.

Catholic sects operating in the Ottoman geography; The Jesuits in 1583, The Observants in 1584, the Capuchins in 1587, Riformati in 1630, Lazariste in 1783, Filles de la Charite in 1838, Fréres des Ecoles Cheretienes in 1842, Notre Dame de Sion in 1861 The Georgian Catholic continues in the form of the Italian Ivrea Priests of 1869, while the Protestant sects; The American Board of Commissioners for Foregin Mission-ABCFM, The American Bible Society (ABS), The American Tract Society, Presbyterian Board, The American Friends' Mission, Armenia and The National Armenia and Indian Relief Association, Reformist Churches Union, Young Men Christian Union, Young Women Christian Union, Methodists, The Near East Relief.

In the 19th century, mission work became systematic, and each Christian Foreign State carried out its own mission work. Although Christianity was divided into separate branches as Catholic, Protestant and Orthodox, they carried out separate mission works under the auspices of states in particular.

The French mission work, which is one of the missions carried out specifically for foreign states, dates back to the $16^{\text {th }}$ century. In addition to obtaining commercial concessions from the Ottoman Empire through Capitulations, the French began to gain privileges in the religious field as of the $17^{\text {th }}$ century. Thus, the French acted as the sole and true guardians of the Christian mission carried out in the Ottoman lands.

The first Catholic school established in the Ottoman Empire was St. Benoit School. The school was opened by Jesuit priests. Another important Catholic school is St. Louis Language School. Louis Language School, gave language training to mission 
officials in the east. The officials who were educated here carried out activities in Anatolia and the Holy Land under the auspices of France.

Among these activities, Mamuratü'l Aziz, an important station, draws attention. Mamuratü'l Aziz and Harpoot is a settlement that has been used since the Urartians, and its proximity to trade routes to the north and east gives this region a strategic importance. Although the region of Harpoot and Mamuratü'l Aziz was under the rule of the Ottomans since the $16^{\text {th }}$ century, it was under the Diyarbakir Province, it was governed as a separate province from the middle of the $19^{\text {th }}$ century. In addition to the American Protestant missionary in Harpoot, the French Capuchin mission also operated in this region.

In the Ottoman archives, as it is understood from the document "Appointment of the French Consul Deputy" in Harpoot in 1859, there was a community under the auspices of the French. The properties of the Capuchins reflected in the Ottoman archive documents in Harpoot and the abundance of construction activities they carried out in these properties show that an active mission field is working. With this motivation, it has been determined that the Capuchins also opened a French school in Mamuratü'1 Aziz.

In the Mamuratü'l-Aziz Province yearbooks (1869-1907) that there are Armenian girls and boys schools. Girls and boys schools belonging to Kapusen priests in Gürcübey District. The number of female students belonging to Capuchins is 30 and the number of male students is 60 .

Four different buildings with architectural drawings of the Capuchins in Harpoot and Mamuratü'l Aziz were seen in the Ottoman Archive documents. One is for church building, the others are educational buildings in the form of renovation or reconstruction. The most comprehensive one among these structures is Capuchins French College located in Mamuratü'l Aziz. The complex has three different buildings in the large land, one of the buildings is a church and the other two are housing and education structures.

After the First World War, the mission activities here were stopped. Kapusen French College was used by the Directorate of Education (Ministry of Education) for this period. However, none of these buildings have survived to the present day.

Considering the number of buildings and the quality of the building understood through the visuals, Mamuratü'l Aziz and Kapusen in Harpoot suggest that the mission is structured with a long-term and permanent understanding. 


\section{Giriş}

"Misyon" ve "misyoner" kelimeleri Fransızca, İngilizce ve Almanca gibi dillerde benzer kelimelerle ifade edilmekte olup (missionary-missionarie, missinoär) Latince (missio) yetki, vekalet, bir kişiye bir iş için verilmiş özel görev anlamlarına gelmektedir ${ }^{1}$. Misyon ve Hristiyanlık tarihî süreç içerisine yan yana anılmış olup Hristiyan din adamlarının temel vazifelerinden biri olarak görülmüsstür. Bu terim, 16. yüzyılda Cizvitler tarafından daha özel bir anlamda sömürge bölgelerine gönderilen kilise görevlileri için kullanılmıştır.

Dinin yayılması ve öğretilmesi faaliyeti olan misyonun İslam'daki karşı1lı̆̆ tebliğ kavramı çerçevesine oturmakta olup sadece doğruların söylenmesi ve aktarılması temel yaklaşımdır. Fakat misyonerlikte insanların vaftiz edilip Hristiyanlaştırılması amaçlanmakta, bu tutum Aziz Pavlus'un Korintoslulara gönderdiği mektuptaki ifadeden "ne yapıp edip insanların Hristiyanlığa kazandırılması" öğütü ile temellendirilmektedir².

Bu çalışmanın temel amacı, Osmanlı coğrafyasında yürütülen misyonerlik faaliyetlerinden Fransız misyonuna, özelde de Fransız Kapusen Rahiplerinin Anadolu'daki faaliyet alanlarına dikkat çekmektir. Hristiyan misyonerliğinin Osmanlı topraklarındaki faaliyetleri 15. yüzyıla kadar indirilse de Anadolu ve diğer bölgelerindeki etkin misyonerlik çalışmaları daha çok 19. yüzyılda görülmektedir.

Bu çalışma üç ana bölümden oluşmakta olup öncelikle Hristiyan misyonerliğinin Osmanlı coğrafyasındaki genel faaliyetlerine değinilecektir. Daha sonra Fransızların Osmanlı Devleti'ndeki misyon çalışmalarının genel çerçevesi ortaya konulmaya çalışlacak, son olarak Fransız Kapusen rahiplerinin Anadolu coğrafyasında önemli bir misyon noktası olan Mamuratü'l Aziz'deki inşa faaliyetleri aktarılacaktır.

\section{Osmanlı'da Misyon Faaliyetleri}

Osmanlı Devleti'nde misyonerlik faaliyetlerinin 15. yüzyıl Fransız Katolikleri tarafindan başlatıldığ $1^{3}$, daha sonra Cizvit rahiplerinin 8 Kasım 1583'te İstanbul'a geldiği bilinmektedir. Cizvit rahipleri Galata'daki Saint Benoit Manastırı'na yerleşmişlerdir. İstanbul'da bilinen en eski misyonerler ise 1220 tarihinde şehre gelen Konventüel (Conventuel) rahipleridir. 13. yüzyılda geldiği iddia edilen bir diğer tarikat ise Dominikenlerdir. İstanbul'a gelen bu Katolik tarikatlarının temel amacı Greklerin Katolikleştirilmesidir ${ }^{4}$. Misyonerlerin gözünde Osmanlı Devleti’nin önemli olmasının sebebi Hristiyanlığın doğduğu kutsal topraklar ile "Bible Land" olarak misyon kitaplarında

1 Erdal Açıkses, Amerikalıların Harput taki Misyonerlik Faaliyetleri (Ankara: Türk Tarih Kurumu Basımevi, 2003), 3.

2 Şinasi Gündüz, "Misyonerlik", Türk Diyanet Vakfi İslam Ansiklopedisi, c. 30 (İstanbul: Türk Diyanet Vakfi Yayınları, 2005), 193-199.

3 Mustafa Kaan Sağ, "Osmanlı Başkenti İstanbul'da Britanya Kökenli Misyoner Okulları ve İskoç Bir Yapı Ustası: Nicholson Burness" (Doktora Tezi, İstanbul Teknik Üniversitesi, 2017), 23.

4 Tülin Taş, 19. Yüzyll Anadolu'da Katolik Misyonerlerin Eğitim Alanındaki Faaliyetleri (Yüksek Lisans Tezi, Erciyes Üniversitesi, 2006), 114. 
geçen Anadolu coğrafyasının üzerinde yer almasıdır. Osmanlı coğrafyasına gelen Katolik misyoner tarikatlar ve rahipler sirasiyla 1583'te Cizvitler, 1584'te Observantlar, 1587'de Kapusenler, 1630'da Riformati, 1783 Lazariste, 1838'de Filles de la Charite, 1842'de Fréres des Ecoles Cheretienes, 1857'de Notre Dame de Sion, 1861 'de Gürcü Katolik, 1869 İtalyan İvrea rahipleri şeklinde devam etmektedir ${ }^{5}$.

Papalık misyonerlik faaliyetlerini Papa XV. Gregoire (1623) döneminde Vatikan'da kurulan Propoganda Kongregasyonu (La Sainte Gongrégation de la Propaganda) bakanlığ1 ile yürütmüş, İstanbul'a 1655'te Osmanlı Devleti'ndeki bütün Katoliklerin bağlı olduğu Papa vekilliğini oluşturmuştur ${ }^{6}$. Osmanlı Devleti'ndeki Katolik misyonerlerin Türkleri Hristiyanlaştırmak, Rum ve Ermenileri ise Katolikleştirmek gibi emelleri olmuş fakat Müslümanları Hristiyanlaştırmak zor olduğundan Rum ve Ermeni azınlıklara yönelmişlerdir ${ }^{7}$. Hristiyan Katolikliğinin Osmanlı coğrafyasında imtiyaza sahip olması 1604 verilen kapitülasyonlar ile başlamaktadır. Kanuni Dönemi’nden beri Fransızlara verilmekte olan kapitülasyonlar ticari içerikli olup 17. yüzyıldaki imtiyazlara dini ayrıcalıklar da eklenmiştir ${ }^{8}$. Misyonerlik faaliyetleri genellikle eğitimögretim alanında faaliyet gösterip yasal zeminini bu alanda oluşturmuştur. Kilise veya konsolosluğa bağlı olan bu kuruluşlar teoloji (ilahiyat) temelli bir eğitim programı ile beraber meslek ve temel bilimler eğitimleri de vermişlerdir.

Osmanlı Devleti’nde faaliyet gösterecek yabancı veya misyoner okullarının yasal çerçevesi 1869 yılında yayımlanan Maarif-i Umumiye Nizamnamesi ile oluşturulmuştur. Bu nizamnamenin 129. maddesi yabancı okullara ait konuları içermektedir. Maddede yabancı okulların tanımı, masraflarının nasıl karşılanacağı ve açılması için gerekli şartlar belirtilmiştir. İlgili maddeye göre gerekli şartlar; Maarif Nezareti veya Mahalli Maarif Müdürlüğü'nden onaylı öğretmenlerin diploması, ders kitapları, program ve Maarif Nezaret ruhsatının başvuru dosyasında bulunmasıdır'. Bu şartların yanında yapılmak istenen okulun inşası için arsanın sened-i hakanisi de istenmektedir. Bu senette arazinin cinsi, mülk durumu gibi veriler yer alıp yetkililer tarafından kontrolü yapılmaktadır. Bunların yanında okulun yatılı ise masraflarının nasıl karşılanacağı ile yapılacak yerde bir sakınca olup olmadığı da araştırılmaktadır ${ }^{10}$. Osmanlı topraklarında başlıca eğitim faaliyetleri gösteren Katolik tarikatlar; Observant, Konventüel, Kapusen, Dominikan, Cizvit, Karmelit, Lazaristler, Filles de la Charité, Notre Dame de Sion, Immaculeé Conception de Notre Dame de Lourdes Rahipleri, Fréres des Ecoles Chrétiennes, Fréres Maristes, Salésien, Assomption rahip ve rahibelerinden oluşmaktadir ${ }^{11}$.

5 Taş, "19. Yüzyll Anadolu'da Katolik Misyonerlerin Eğitim Alanındaki Faaliyetleri", 17.

6 Taş, "19. Yüzyll Anadolu'da Katolik Misyonerlerin Eğitim Alanındaki Faaliyetleri”, 19.

7 Taş, "19. Yüzyll Anadolu'da Katolik Misyonerlerin Eğitim Alanındaki Faaliyetleri”, 21.

8 Taş, "19. Yüzyll Anadolu'da Katolik Misyonerlerin Eğitim Alanindaki Faaliyetleri”, 26.

9 Tuğrul Özcan, Merkezî ve Modern Eğitim Kapsamında Osmanlı Gayrimüslim Cemaat ve Yabancı Okulları, (İstanbul, Gece Kitaplığı, 2017), 37-39.

10 İlknur Polat Haydaroğlu, Osmanlı Imparatorluğu’nda Yabancl Okullar (Ankara: Kültür Bakanlığı, 1990) 24-33.

11 Ekrem Aksoy, “Başlangıcından Günümüze Türkiye'de Fransız Okulları”, Synergies Turquie 8 (2015), 29-46. 
18. yüzy1l sonu Fransa devrimi ile başlayan siyasi yönetim anlayışındaki değişim Hristiyan dini cemaatlerin faaliyet ve işlerinin azalmasına sebep olmuştur. Devletlerdeki laik yaklaşımlar ile tarikat merkezleri kapanmaya başlamıştır. Fransa'da 13 Şubat 1790 meclis kararında tüm dini tarikatların kaldırılması yönünde karar alınmıştır. 1796 Belçika'da manastırlar kapatılmış, 1802'de Piedmont ve Savoy'da dindarlar sürgün edilmiş, 1803 'te Almanya'da, 1810'da İtalya' da benzer durumlar yaşanmıştır. Bu yüzyılda Hristiyan tarikatlar Krallıklar altında faaliyet göstererek milli kiliseler kurulmaya başlamıştır ${ }^{12}$. 1897'de Observantlar, Konvatürler ve Kapusenler XIII. Leo tarafından tek bir genel başkana bağlanmıştır' ${ }^{13}$.

Hristiyanlığın diğer bir mezhebi olan Protestan misyonu da 19. yüzyılın ilk çeyreğinden itibaren İngiliz ve Amerikan cemaatleri tarafından başlamıştır. Osmanlı topraklarındaki bu misyon faaliyetleri, genel olarak Amerikan cemaatleri özelinde gerçekleşmiş olup The American Board of Commissioners for Foregin Mission (ABCFM) cemaatine bağlı olan Pliny Fisk ve Levi Parsons'un 15 Ocak 1820 tarihinde İzmir'e ayak basması ile başlamışıır' ${ }^{14}$. Bu tarihten sonra Anadolu'da birçok önemli bölgeye yayılmış olan cemaatlerin, özelikle 1895 'te cereyan eden olayların görüldüğü bölgelerde (Mamuratü'l-Aziz, Van, Erzincan, Erzurum, Sivas, Maraş, Merzifon, Diyarbakır, Urfa) yapılandıkları dikkat çekmektedir. Osmanlı coğrafyasında faaliyet gösteren Amerikan Protestan cemaat örgütleri; American Board (The American Board of Commissioners for Foregin Mission-ABCFM), Amerikan İncil (The American Bible Society-ABS), Amerikan Risale (The American Tract Society), Presbyterian Board, Amerikalı Kardeşler (The American Friends' Mission), Ermenistan ve Hindistan Milli Yardım Birliği (The National Armenia and Indian Relief Association), Reformist Kiliseler Birliği, Genç Erkekler Hristiyan Birliği, Genç Kadınlar Hristiyan Birliği, Metodistler, Yakın Doğu Muavenet Heyeti (The Near East Relief)'dir ${ }^{15}$. Protestanlığın bir diğer hami devleti İngilizler olup Osmanlı topraklarında faaliyetleri, imzaladıkları ticaret anlaşmaları (Baltalimanı Antlaşması, 1838) çerçevesinde hız kazanmıştır. 1840'lardan itibaren İngiliz topluluğuna ait olan misyoner cemaatler başta İstanbul ve Kudüs'te olmak üzere çok sayıda yapı inşa etmişlerdir ${ }^{16}$. Bir diğer Protestan millet Almanlar olup Alman birliğinin kurulmasından (1871) sonra Alman misyonu Osmanlı coğrafyasında faaliyetlerini Van, Muş, Mamuratü'l-Aziz ve Maraş’ta merkezi noktalar ile faaliyetlerini yürütmüşlerdir ${ }^{17}$.

12 Mehmet Çoban, "Bir Katolik Cemaati Olarak Fransiskenler" (Yüksek Lisans Tezi, Marmara Üniversitesi, 2008), 147.

13 Çoban, "Bir Katolik Cemaati Olarak Fransiskenler", 90.

14 Sağ, "Osmanlı Başkenti İstanbul'da Britanya Kökenli Misyoner Okulları ve İskoç Bir Yapı Ustası: Nicholson Burness," 25.

15 Gülbadi Alan, Osmanlı İmparatorluğu'nda Amerikan Protestan Okullarl, (Ankara: Türk Tarih Kurumu Yayınları, 2015). ABCFM örgütü 1810 'da Boston'da kurulmuştur. Örgüt sadece Osmanlı coğrafyasındaki misyon faaliyetlerini değil, dünyada yürütülecek çalışmaların da temelini oluşturmuştur.

16 Sağ, "Osmanlı Başkenti İstanbul'da Britanya Kökenli Misyoner Okulları ve İskoç Bir Yapı Ustası: Nicholson Burness, "14.

17 Uğur İnan, Osmanlı Devleti’nde Almanlarin Protestan Misyonerlik Faaliyetleri (Ankara: Türk Tarih Kurumu Yayınları, 2015), 52. 


\section{Osmanlı'da Fransız Misyonu}

Misyonerlik, Katoliklik ve Protestanlık olmak üzere iki ana grupa ayrılmış, Fransız himayesindeki Katolik misyonerlerin Osmanlı toprakları içerisinde yürütmüş oldukları faaliyetler 16. yüzyıla kadar dayanmaktadır.

Papa X. Leo tarafindan 1517'de Katolik tarikatlarından Fransiskenler, Observant ve Konvantüller olarak ikiye ayrılmıştır ${ }^{18}$. Sonraki yıllarda Observantlar içerisinde yenilikçi bir hareket olan Kapusenler ortaya çıkmıştır. Bu hareketin önderi İtalya'nın Marches şehrinde yaşayan ve genç bir keşiş olan Matteo de Basci'dir. Kapusenler, Aziz Frencesco gibi giyinip, tunik gömlek üzerine koni başlık takmışlardır. Resmi olarak "Little Hood" veya "Cappuccinni” olarak adlandırılmışlardır. Kapusenler, 1619'da bağımsız bir yapı kazanıp Fransiskenler içinde Observant, Konvantüller ve Kapusenler diye üç ana grup oluşmuştur ${ }^{19}$. 17. yüzy1lda Kapusenler İtalya ve komşu adalarda 23, Fransa'da 8, İspanya'da 4, Flandra'da 2 ve diğer Avrupa ülkelerinde 5 yönetim merkezi kurmuştur ${ }^{20} .1551$ yılında Kapusen tarikatına mensup iki rahibin İstanbul'da misyonerlik faaliyeti yapmaya çalıştığ 1 ve Osmanlı Devleti'nin buna müsaade etmediği de kaynaklarda geçmektedir ${ }^{21}$. Kapusen tarikatı, 1630'dan beri Mardin, Musul, Diyarbakır'da faaliyet göstermiş fakat 1667 'de sadece Diyarbakır şubesi kalmışıır'22.

Osmanlı Devleti'nde kurulan ilk Katolik okulu 1583 tarihli Galata'daki St. Benoit Okulu'dur. Okul Cizvit rahipleri tarafindan açılmıştır. Diğer önemli Katolik okulu ise 1625 yılında Kapusenler tarafindan kurulmuş olan Pera'da Fransız Konsolosluğu'nun içinde bulunan St. Louis Dil Okulu'dur ${ }^{23}$. Bu dil okulunda doğuya gidecek misyon üyesi ve diplomatlar eğitim görmüştür. Dil okulunun 1785 'te Paris'te açılan Yaşayan Doğu Dilleri Okulu sebebiyle zamanla etkinliği azalmıştır ve Louis Dil Okulu 1873’te kapanmıştır ${ }^{24}$ (G. 1). 1897 tarihli salnamede Osmanlı topraklarında Fransızlara ait 50 iptidai, 40 rüştiye, 28 idadi olmak üzere 127 tane okul bulunmaktadır ${ }^{25}$. 1901'de meşruiyet kazanmış Fransız okul sayısı 259 olup bunlardan 17 tanesi Kapusenlere aittir. Yine bu tarihli Fransızlara kayıtlı ibadethane, hastane, mezarlık ve hayır kurumları ise 477 adettir $^{26}$.

1900'lerde Jean Baptiste Piolet yazdığ İstanbul misyonu mektubunda Kapusenler'in 1629'da Papalık tarafından etkin bir misyon olarak görüldüğünü, 17.

18 Çoban, "Bir Katolik Cemaati Olarak Fransiskenler", 73.

19 Çoban, "Bir Katolik Cemaati Olarak Fransiskenler", 85.

20 Çoban, "Bir Katolik Cemaati Olarak Fransiskenler", 88.

21 Mehmet Aydın, “Türkiye’ye Yönelik Katolik Misyonerliğin Dünü ve Bugünü”, Türkiye'de Misyonerlik Faaliyetleri (İstanbul: İslami İlimler Araştırma Vakfi, 2004), 93-122.

22 Oktay Bozan, Osmanl Döneminde Amerikan Misyonerlerinin Diyarbakır Vilayetine Gelişi ve Faaliyetleri, Dicle Üniversitesi Sosyal Bilimler Enstitüsü Dergisi 13 (2015), 333-361.

23 Özcan, "Merkezî ve Modern Eğitim Kapsamında Osmanlı Gayrimüslim Cemaat ve Yabancı Okulları", 111.

24 Aksoy, "Başlangıcından Günümüze Türkiye'de Fransız Okulları”, 32.

25 Taş, "19. Yüzyll Anadolu'da Katolik Misyonerlerin Eğitim Alanındaki Faaliyetleri”, 34.

26 Şerife Yorulmaz, "Osmanlı Fransız İlişkileri Çerçevesinde Osmanlı Topraklarında Açılan Fransız Kültür Kurumları ve Bunların Meşruiyet Kazanması (19.yy-20.yy başları)", Ankara Üniversitesi OTAM Dergisi 11 (2000), 697-768. 
yüzyılın sonuna doğru Damas, Saida, Beyrut, Cezayir, Kahire, Kıbrıs, Diyarbakır, İzmir ve Atina merkezlerinin oluştuğunu belirtmiştir. Piolet, Pera'daki Büyükelçilik binası yanındaki dil okuluna gelen öğrencilerin sadece İstanbul'dan değil Anadolu'dan ve Kutsal topraklardan da getirildiğini aktarmıştır. Mektupta, 1792'de Kapusen misyonu ve onu temsil eden Saint Louis Kilisesi'nin Fransa Krallığı'na hizmet edecek şekilde düzenlendiğine fakat genel misyonunun korunduğuna dikkat çekmiştir. Bu sebeple Anadolu'nun en ücra köşelerine okulların açılmasının misyon tarafından devam ettirildiğini ve 1892'de İstanbul-Kadıköy'deki elden geçirilen eski Hristiyan okulunun Anadolu'daki ve Kutsal topraklardaki misyon bölgelerine gidiş için temel noktalardan biri olduğunu Piolet mektubunda not etmiştir ${ }^{27}$.

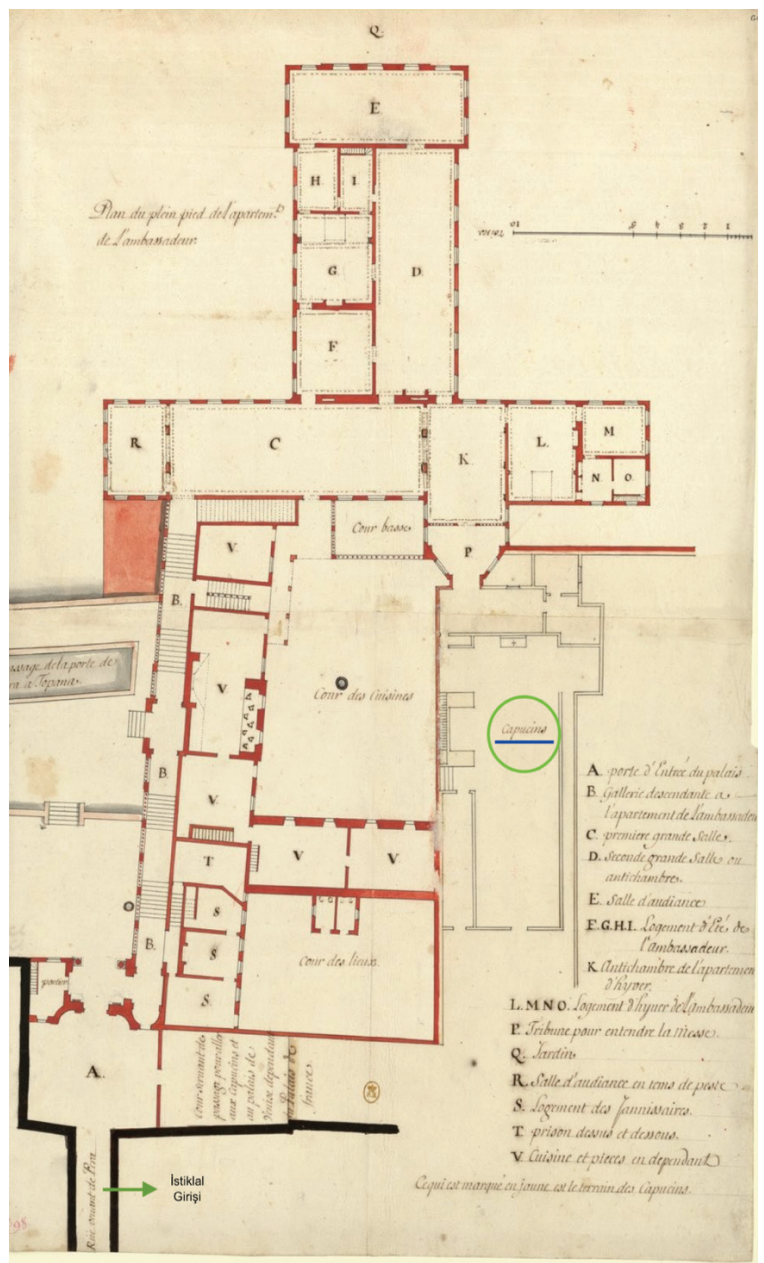

G. 1: 1722 tarihli Pera'daki Fransız Konsolosluğu Planı ve Kapusen Dil Okulu (Ambassade de France à Constantinople, 20 Aralık 2020, https://gallica.bnf.fr/ark:/12148/ btv1b53043303z?rk=429186;4)

27 Haktan Birsel, "Fransız Misyonerler Tarafindan İstanbul ve Levant Misyonun Oluşturulması (Papaz J. Paptist Piolet'nin Mektubu)", Turkish Studies 9/4 (2014), 207-23. 
Kapsusenlerin 19. yüzyıldaki Doğu misyonu 1822'de kurulan "İnancın Yayılması Birliği” ile 1856'da kurulan "Doğu'da İnancın Yayılması Birliği Okulları (l'Oeuvre des écoles d'Orient)" tarafindan yürütülmüştür ${ }^{28}$.

\section{Mamuratü'l-Aziz Vilayeti'nde Kapusen Misyonu}

Mamuratü'l-Aziz vilayetinin yaygın yerleşim bölgesi olarak kullanılan iki noktası bunulmaktadır: İlki Harput olup bölgenin yerleşim tarihi Urartulara kadar dayanmaktadır. Diğer nokta ise 19. yüzyılın ortalarından itibaren vilayet merkezi olarak gelişen ve günümüz Elazığ il merkezini oluşturan Mamuratü'l-Aziz'dir.

Harput, Doğu Anadolu Bölgesi’nde Elazığ şehrine 5 km uzaklıkta deniz seviyesinden 1280 metre yükseklikte kısmen yüksek kayalıkların ve kısmen de düz bir arazinin olduğu bir yerleşim yeridir. Harput, İpek Yolu üzerinde önemli ticaret merkezlerinden biri olan Malatya'ya $100 \mathrm{~km}$ mesafede konumlanmaktadır ${ }^{29}$. Yunan coğrafyacısı Strabon'a göre Harput isminin kökeni bu bölgede bulunan Karkathiokerta ile Arsamosanta adlı iki şehirden biri olan Karkathiokerta'dır. Süryanice kaynaklarda Hisnâ de Ziyad, Arap coğrafyacılardan edinilen bilgilere göre Harput Kalesi için Hisn-ı Ziyad, kalenin yerleşmiş olduğu şehre ise Hartabird denmektedir. Harput isminin Ermeniceden neşet ettiği de söylenmektedir. Buna göre Hisar manasında "Bert" ve taş, kaya manalarında "Har" kelimeleri birleştirilerek "Taş Kale" anlamında Harbert kelimesinin kullanıldığı belirtilmektedir ${ }^{30}$. Bu görüşlere ek olarak ismin kaynağ 1 Urartu ve Hurriler’e de dayandırılmıştır. Son hecede yer alan bert veya pert ibaresinin Urartu dilinde şehir anlamına gelen gert kelimesinin bir varyantı olduğu ileri sürülmüştür. Harput, Asur çivi tabletlerinde karpata, Bizans kaynaklarında Kharpote, Frenk tarihçilerin metinlerinde Quartapiert şeklinde geçmektedir. Osmanlı devri kaynaklarında ise günümüzdeki hâlinin yanında Hartabird, Harpurt, Harpurd, Hârbüt şeklinde kullanımına da tesadüf edilmektedir ${ }^{31}$.

Harput tarihi MÖ 4-3 binlere kadar dayandırılıp Subarların bu çevrede yaşadıkları kaynaklarda geçmektedir. Fırat isminin de Subarlar tarafindan verildiği arkeolojik kazılarda tespit edilmiştir. Subarlardan sonra sırasıyla Hititliler ve Urartular bölgede hakimiyet sürmüştür. 1. yüzyıldan sonra bölge Roma hakimiyetine girmiş, Hz. Ömer'in hâlifeliği döneminde İslam orduları Harput'u fethetmiştir. Harput 10. yüzyıla kadar Hamdanoğulları'nın elinde kalmıştır. 10. yüzyıldan sonra Harput ve çevresi Doğu Roma hakimiyetinde idare edilmiş Malazgirt Savaşı sonrası Emir Çubuk tarafından bölge Çubukoğulları hakimiyetine girmiştir ${ }^{32}$. Bizans döneminde Harput hakkında

28 Yorulmaz, "Osmanlı Fransız İlişkileri Çerçevesinde Osmanlı Topraklarında Açılan Fransız Kültür Kurumları ve Bunların Meşruiyet Kazanmast (19.yy-20.yy başları)," 711.

29 İsmail Aytaç, "Malatya-Harput Kervan Yolu Güzergahı ve Kervansarayı", Dünü ve Bugünüyle Harput Sempozyumu; Tarih, Edebiyat, Şiir, Folklor (Elazığ: Türkiye Diyanet Vakfı Elazığ Şubesi Yayınları, 1999), 225-247.

30 Mehmet Ali Ünal, XVI. Yüzyllda Harput Sancağı (1518-1566) (Ankara: Türk Tarih Kurumu Basımevi, 1989), 11-12.

31 Ünal, XVI. Yüzyllda Harput Sancă̆ (1518-1566), 11-12.

32 Nureddin Ardıçoğlu, Harput Tarihi (Ankara: Yükseköğretim Kurulu, 1997), 114-118. 
yeterli bir kaynak bulunmamaktadır. Sadece dönemin kaynaklarında Harput kalesinin mevcudiyeti, Bizans döneminde Harput'un bir kale-şehir olduğunu göstermektedir ${ }^{33}$. 1087 yılında Çubuk Bey'in Harput'u alması ile şehir eski varlığını devam ettirmiş, yeni gelen Türkmen grupları tarımsal arazilerde konumlandırılmıştır. Çubuk Bey döneminden (1087-1113) günümüze ulaşmış yapı bulunmamaktadır. Harput 10. yüzyılda Çubukoğlu Beyliği, 11. yüzyılda Artukoğlulları, 13. yüzyılda Selçuklular, 14. yüzyılda Dulkadiroğlu Beyliği, 15. yüzyılda Akkoyunlular ve son olarak da 16. yüzyıldan itibaren Osmanlı Devleti hakimiyetinde bulunmuştur ${ }^{34}$.

Diğer yerleşim yeri olan bölge ise, Harput'un "Agavat Mezrası" ismi ile bilinmekte olan Mamuratü' l-Aziz'dir (G. 2). Burası 1867'de Harput Eyalet Meclisi'nin isteği ve Bâb-1 Âli'nin onayıyla Sultan Abdulaziz'e ithafen bu şekilde adlandırılmıştır. 19. yüzy1lın ilk çeyreğinden beri Harput ve Diyarbakır vilayet valileri Harput'ta ikamet etmiş, 1856'dan sonra Mamuratü'l-Aziz'deki Hükümet Konă̆g'nda hizmet vermişlerdir ${ }^{35}$. Vali konağının Mamuratü'l-Aziz'e taşınması ve 1866'daki Harput yangınlarından sonra şehir gelişmeye başlamıştır.

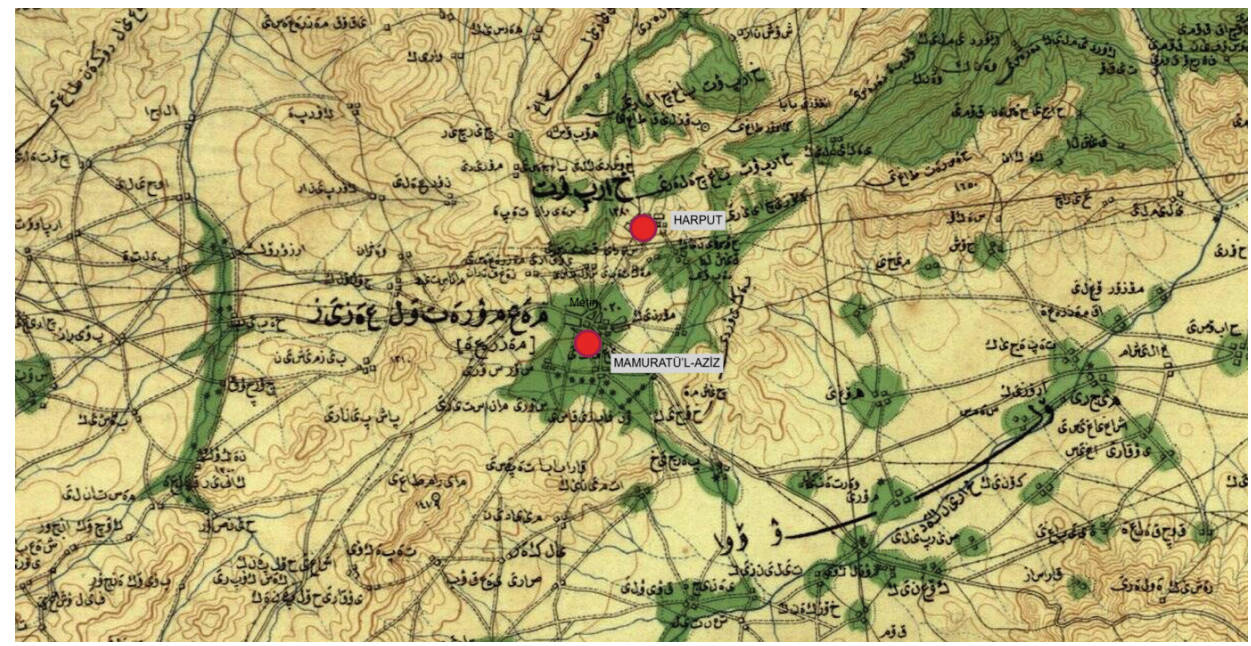

G. 2: 1914 tarihli harita

(Erişim 29 Aralık 2020, https://archives.saltresearch.org/handle/123456789/102338)

16. yüzyılda Harput'un genel nüfusu 13 bin olup 6 binini, 17. yüzyılda ise 5 bin nüfusun bin kadarını gayrimüslimler oluşturmaktadır. 19. yüzyılda genel nüfusta $\% 20$ 0'lük artış olmuş ve genel nüfusun \%28'ini gayrimüslimler teşkil etmiştir. 19. yüzyılda Harput’taki Müslüman mahalleleri; Sara Hatun, Kale, Mescid-i Müderris, Ahmet Bey, Kara Sofu, Ebu Tahir, Zahiriye, Alaca Mescid, Orta Mescid, Ahi Musa, Hacılar,

33 Ertuğrul Danık, "Orta Çă̆ Harput'un Kentsel Gelişimi”, Dünü ve Bugünüyle Harput Sempozyumu; Tarih, Edebiyat, Şiir, Folklor (Elazığ: Türkiye Diyanet Vakfı Elazığ Şubesi, 1999), 71-73.

34 Danık, "Orta Çă̆ Harput'un Kentsel Gelişimi", 71-73,

35 Ahmet Aksın, 19. Yüzyılda Harput, (Elazığ: Ceren Ofset ve Matbaacılık \& Reklamc1lık, 1999), 73. 
Esadiye, Ağa Cami, Meydan, Hoca Mescid, Cami-i Kebir mahalleleridir. Gayrimüslim mahalleler ise, Şehroz, Sinabut, Gürcü Beğ, Asuri, Çelebi olarak sıralanabilir ${ }^{36}$.

Mamuratü'l-Aziz ve Harput'un birbirine yakın olmasından dolayı misyonerlik faaliyetleri iki bölgede de görülmüştür. Bu bölgede Katolik misyonu dışında Protestan misyonerliğine ait çalışmalar da bulunmaktadır. Protestan misyonunu American BOARD ile Alman cemaatleri yürütmüştür. American BOARD 1859'da Harput'ta Teoloji okulunu, 1865'te Protestan Ermeni Kiliseleri Birliğini, 1878'de Firat Kolejini (Ermeni Koleji), 1900'de Harput Amerikan Konsolosluğunu ve 1909'da Mamuratü'l Aziz'de Annie Tracy Riggs Hastanesini açmıştır ${ }^{37}$. Alman misyonerler ise 1895 'teki olayları sebep göstererek Harput'taki yetimlere yardım için şehre gelmiş, misyon 1897'de okul, 1900'de bir Protestan Kilisesi yapmıştır. Yapılan araştırmalarda Mamuratü'l Aziz'de 2 iptidai, 1 rüşdiye, 1 idadi ve sanayi mektebinin Alman Protestan misyonerlerinin idaresinde olduğu belirlenmiştir ${ }^{38}$. Osmanlı arşivlerinde yer alan Harput'ta 1859'da "Fransız Konsolos vekilin tayin edilmesi" 39 içerikli belgeden (G. 3), bölgede Fransa himayesinde yabancıların olduğu ve faaliyet gösterdiği anlaşılmaktadır.

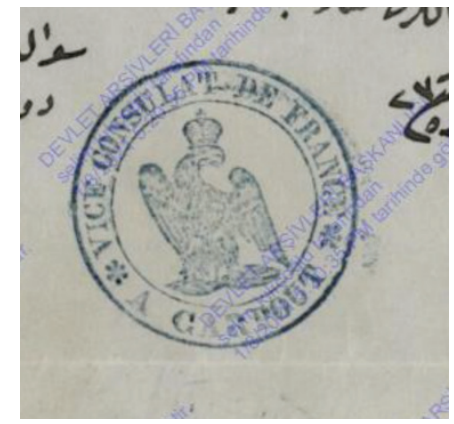

G. 3: Harput'taki Fransa Konsolosluğunun Mührü (B.O.A-İ.HR.172.9321-H 28/03/1276 (25 Ekim 1859)

Mamuratü'l-Aziz vilayet salnamelerinde (1869-1907) Harput Gürcübey Mahallesi’nde Ermeni İptidai kız ve erkek okulu ile Kapusen rahiplerine ait İptidai kız ve erkek okulları olduğu görülmektedir. Kapusen rahiplerine ait olan okullardaki kız öğrenci sayısı 30, erkek öğrenci sayısı ise 60 olarak geçmektedir. Fakat salnamede Kapusen rahiplerinin cemaat adı kısmında karışık yazıldı̆̆ 1 da dikkat çekmektedir ${ }^{40}$. Fransız elçiliği rakamlarına göre 1905 tarihli verilerde Harput, Mezra ve Malatya'da

36 Salih Akyel, 19. Yüzyllın İlk Yarısında Harput Şehrinin Nüfus ve Toplum Yapısl (Doktora Tezi, Fırat Üniversitesi, 2013), 159.

37 İdris Yücel, Anadolu'da Amerikan Misyonerliği ve Misyon Hastanesi, (Ankara: Türk Tarih Kurumu Yayınları, 2017), 224.

38 Uğur İnan, Osmanlı Devleti’nde Almanların Protestan Misyonerlik Faaliyetleri (Ankara: Türk Tarih Kurumu Yayınları, 2015), 462.

39 B.O.A-İ.HR.172.9321-H 28/03/1276 (25 Ekim 1859)

40 Ünal Taşkın, “Maarif Salnamelerinde Mamuratülaziz”, International Journal of Social Science 6 (2013), $1327-1353$. 
Kapusen rahiplerine ait okullarda toplam öğrenci sayısı 152 kişidir. 1901'de 6 okul, 1913 sonrası 10 yapı tespit edilmiştir ${ }^{41}$.

Şura-1 Devlet'te 1884'te okunan yazıda Fransız Kapusen rahiplerine ait Mamuratü'lAziz vilayetindeki Mamuratü'l-Aziz şehir merkezinde olduğu anlaşılan arazi üzerine kilise inşa edilmesi istenmiştir. Yapılan tahkikatlarda aynı arazi üzerinde hastane, mektep, kilise yapılması da gündeme gelmiştir. Yapılmak istenilen kâgir kilise Kışla-1 Hümayun'a ve Talimhane'ye yakın olduğundan Seraskerlikten de izin alınması ve çizimlerinin hazırlanması gerektiği ifade edilmiştir. Kilisenin 24 metre uzunluğu, 14 metre derinliği, 16 metre yüksekliği olacağı belirtilmiştir ${ }^{42}$ (G. 4). 1902 tarihli Meclis-i Vükela'da okunan hülasada aynı yerde mektep yapımı gündeme gelmiş, belirtilen ölçülerin gerçeği yansıtmadığ 1 ve 41x21 metre taban alanı 10.25 metre yüksekliğine sahip bir yapı olduğu bilgisi yer almıştır ${ }^{43}$.

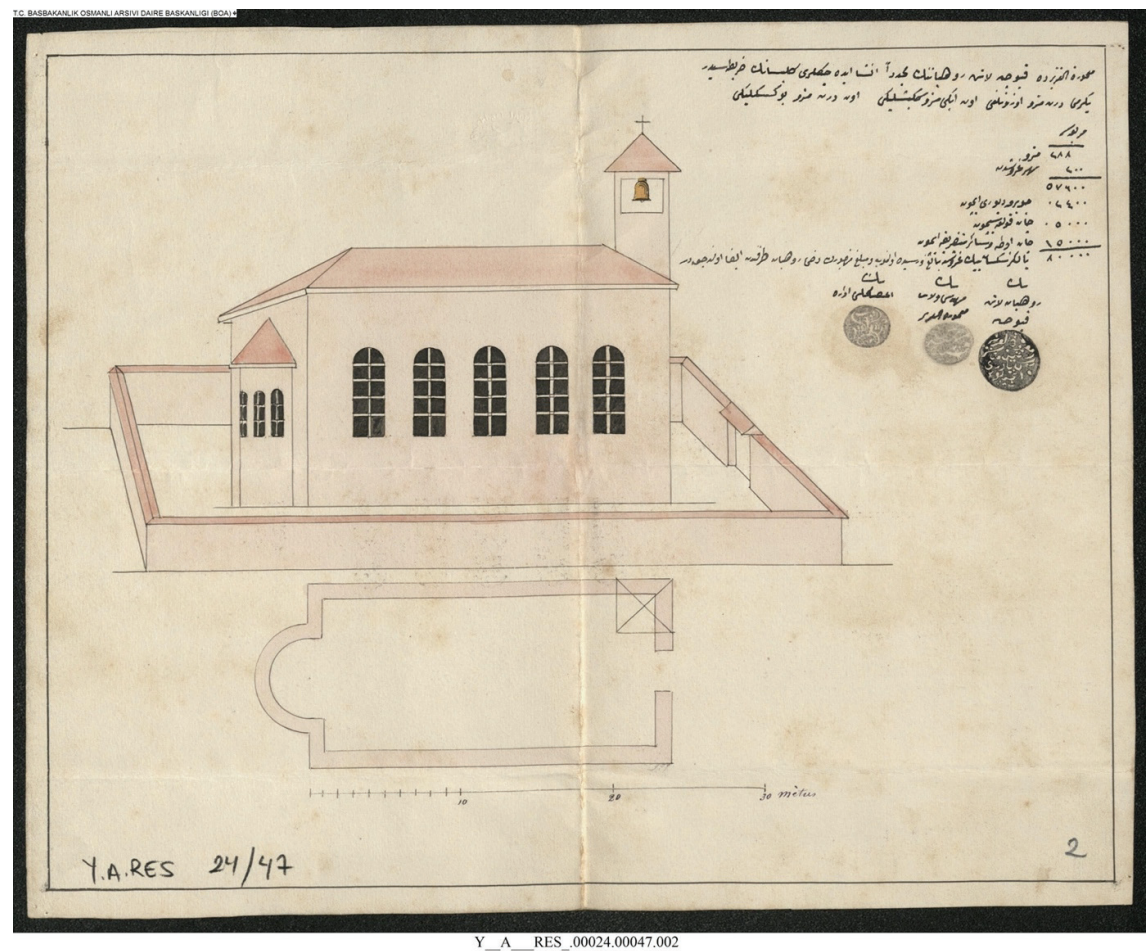

G. 4: Mamuratü'l Aziz'de yapılması istenilen kilise (B.O.A-Y.A.RES.24/47)

Mamuratü'l-Aziz'deki Kapusenlere ait Fransız Kolejinin kaynaklarda 1869'da kurulduğu belirtilmiştir ${ }^{44}$ fakat bu bölgede bulunan en erken tarihli evrak 1884'te inşa

41 Şamil Mutlu, Osmanlı Devletinde Misyoner Okulları (Doktora Tezi, İstanbul Üniversitesi, 1999), 402.

42 B.O.A- Y.A.RES.24/46- H.27.10.1301 (20 Ağustos 1884)

43 B.O.A-MV.104 -H. 14.04.1320 (21 Temmuz 1902)

44 Taş, “19. Yüzyıl Anadolu’da Katolik Misyonerlerin Eğitim Alanındaki Faaliyetleri”’37. 
edilmesi istenen kilise hakkındadır ${ }^{45}$. Kışla-1 Hümayun ve Talimhane'ye yakın olan Mustafa Paşa Mahallesi’ndeki (günümüzde Elazığ merkezinde bulunmakta) bu mülkün 19. yüzyılın son çeyreğine ait vergi evrakına rastlanmaktadır.

1916'da Maarif Nezaretine devri gerçekleşen Mamuratü'l-Aziz'deki Fransız Kolejin mevcut hâlinin ne zaman yapıldığ 1 tespit edilememiştir. Maarif Nezaretine devir işlemi esnasında yapının vaziyet ve kat planları detaylı bir şekilde çıarılmış, Nezaretin kullanımı için yapı yeniden işlevlendirilmiştir. Mamuratü'l-Aziz'deki Fransız Koleji bir kilise binası ile iki okul binasından oluşmuş ve yapılarından biri kız diğeri erkek okulu olarak işlevlendirilmiş, kilise yapısının içerisine oda bölümleri yapılmışıı ${ }^{46}$. Erkek okulu olarak kullanılacak yapının ön cephesinde cumbalı bir çıkma bulunmakta, yörede yapılan evlerin ön cepheleri ile benzerlik taşımaktadır. Kilise yapısının giriş cephesi üzerindeki çan kulesi gotik katedrallerin kule uçlarına benzer formlarda ele alınmış olup yapının diğer kısımları sade, basit kırma çatılı bir mahiyette yapılmışıtır. Eski Fransız Koleji, daha sonra Maarif Nezaretinin uhdesinde bulunan yap1, 1900'lü yıllarına ortasında çıkan yangınla harap olmuş, yapı topluluğu günümüze ulaşamamıştır (G. 5, G. 6, G. 7).

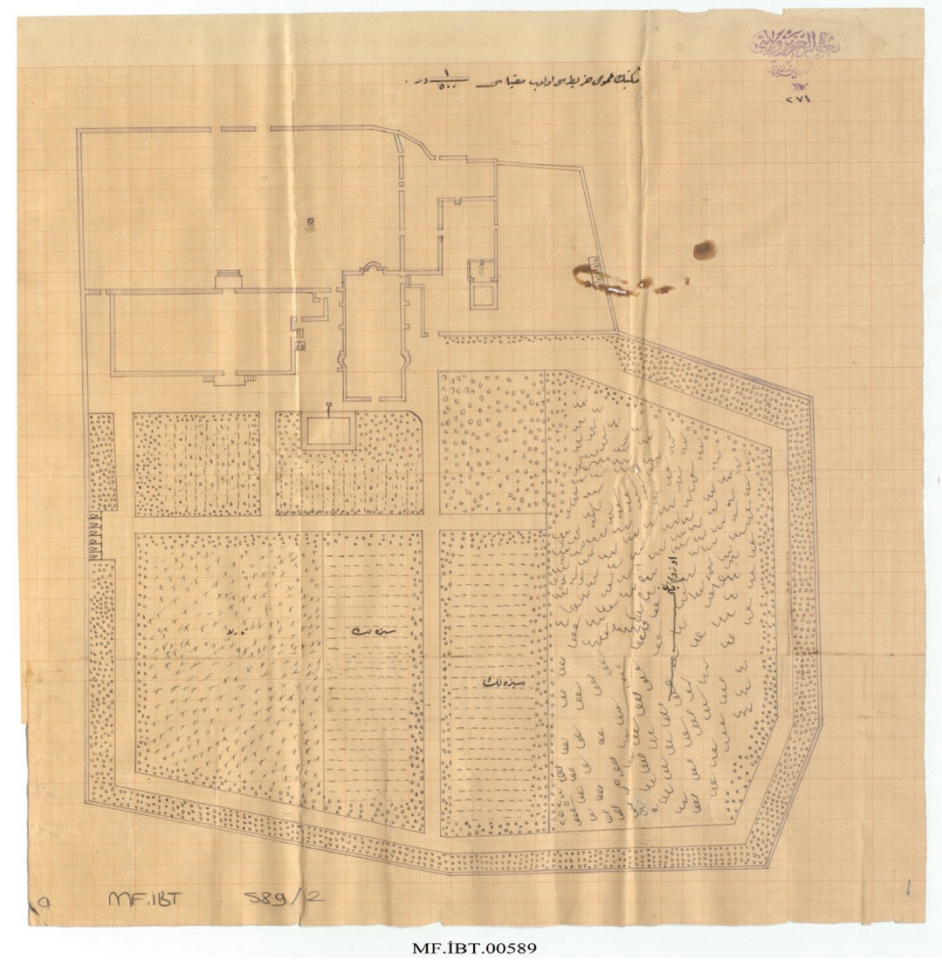

G. 5: Mamuratü'l-Aziz'deki Kapusen Fransız Koleji Vaziyet Planı (mikyas 1/500)

(B.O.A.MF.IBT.00589)

45 B.O.A- Y.A.RES.24/46- H.27.10.1301 (20 Ağustos 1884)

46 B.O.A-MF.IBT.589/ H.17.08.1334 (19 Haziran 1916) 


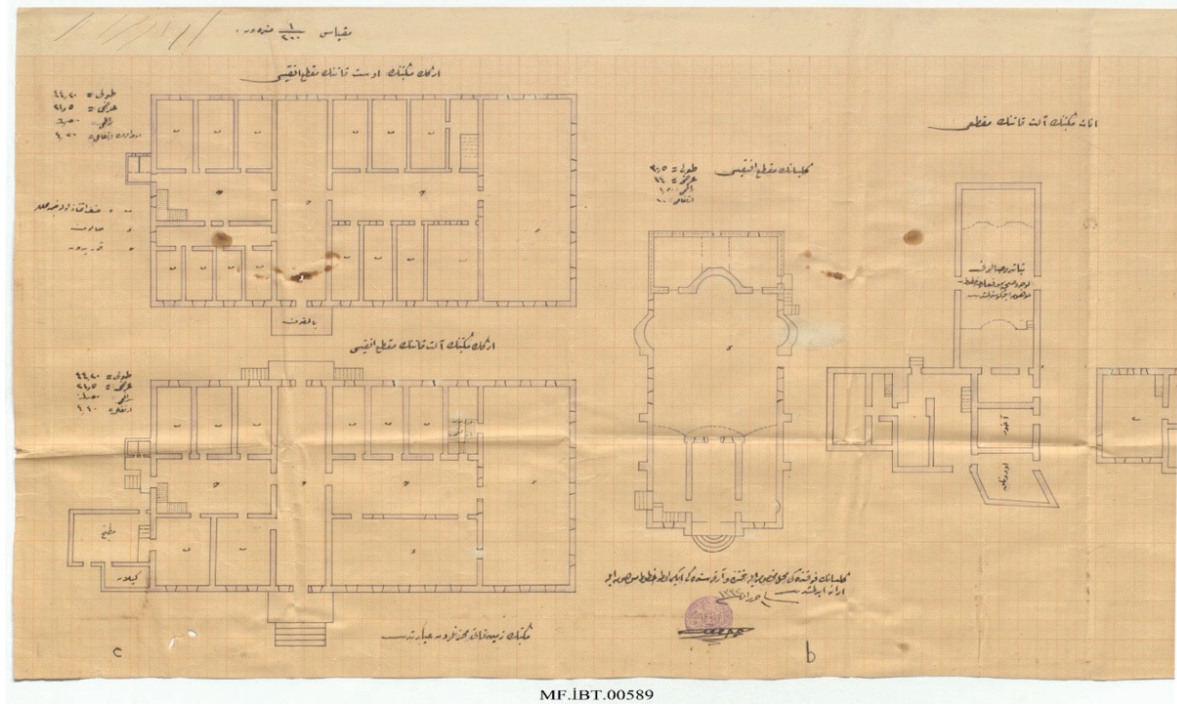

G. 6: Erkek ve Kız Okullu Olarak Kullanılacak Yapılar ve Eski Kilise Yapısı Planları (mikyas 1/200) (Soldan Sağa Erkek Okulu 1. ve 2. kat planları, Eski Kilise, Kız Okulu) (B.O.A.MF.İBT.00589)

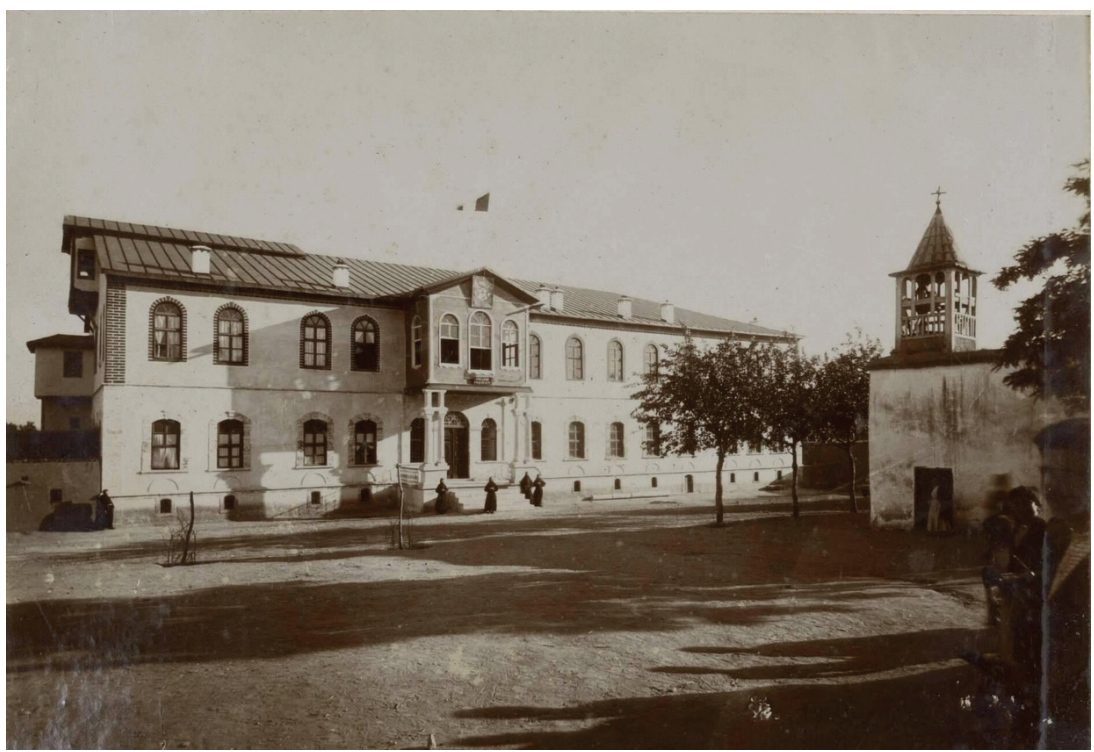

G. 7: Mamuratü'l-Aziz'deki 1904 tarihli Kapusen Fransız Okulu (Raphael, Albüm de la Mission de Mésopotamie er d'Arménie Confiée aux Fréres, Lyon, 1)

Mamuratü'l-Aziz vilayet merkezi dışında merkeze yakın eski yerleşim yeri olan Harput'ta da Kapusen Rahiplerinin kilise ve okul binaları bulunmaktadır. Kapusenlerin Harput'a daha önceden yerleşmiş oldukları bilinmesine rağmen, inşa faaliyetleri en erken 20. yüzyıl başındaki belgelerden takip edilebilmektedir. Harput’ta Kapusenlere 
ait mektep olarak kullanılan binanın tekrardan yapılmasına dair 1903 tarihli evrakta, yapının 16x12 metre ebatlarında 9 metre yüksekliğinde olacă̆ 1 , Maarif ve Hariciye nezaretlerinin onayları ile yapılabileceği belirtilmiştir $(\mathbf{G . ~ 8})^{47}$. Yapının bir bodrum kat, normal kat planları ile ön cephe çizimleri yapılmıştır. Bodrum kata yapının yanından istinat duvarlarıyla tahkim edilmiş 5 veya 6 merdivenle inildiği anlaşılmaktadır. Bodrumda taşıyıcı yan duvarların yanında yapının ortasında 6 taşıyıcı ayak/kolon olduğu görülmektedir. Yapının kat planları ve görsellerindeki pencere açıklıkları birbiri ile örtüşmemekte olup çizimdeki pencere gösteriminden (içeri genişleyen pencere boşluğu) yapının taş malzeme ile yapıldığını düşündürtmektedir.

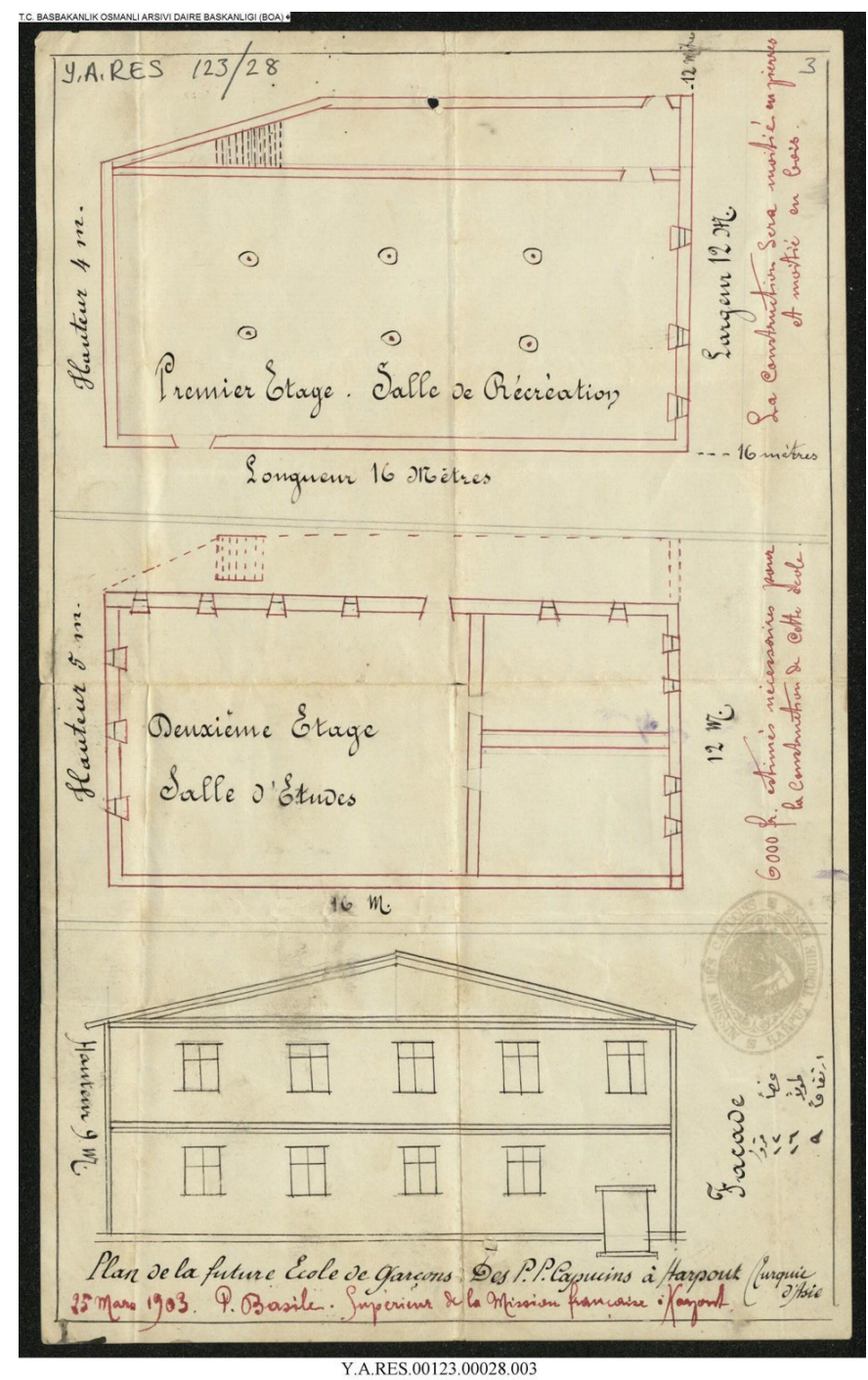

G. 8: Harput’ta Yap1lmas1 İstenen Okul (B.O.A.YA.RES.123/28) 
Bir diğer belge ise, 1909 yılında Kapusen rahiplerinin hanesi olan arazi üzerinde bir mektep ve manastıra ek yapı yapılması hakkındadır. 1903 'teki arazi ile burada inşa edilmiş olan manastır ve mektep yapısı arasında bir bağlantı kurulamadığından okul ve buradaki manastır-mektep yapısının farklı noktalarda olduğu düşünülmektedir. Manastıra ek yapı ve mektep inşa edilmesi istenen hane arazilerinin satın alınma tarihleri $1892^{48}, 1897^{49}, 1905^{50}$ 'tir.

Belgelerde kız mektebi olarak kullanılacak olan yapının inşa faaliyeti sırasında mevcut olan manastır yapısına ilave bir yapı inşa edileceği bilgisi verilmiş ve mektebin yeniden yapılması istenmiştir. Bu yenileme esnasında yapının "sadece mülk" olduğu belirtilmiş fakat arazinin "Pier kapusen" kilisesi olduğu tahkikatlarda yer almıştır. Manastıra ilave edilecek olan bölümün 11x23 metre taban alana, 10 metre yüksekliğe; kızlar için yapılacak olan bölümün ise 30x14 metre taban alana, 12 metre yüksekliğe sahip olacağı evraklardan anlaşılmaktadır ${ }^{51}$. Mektebin kat planları incelendiğinde işlevi belirtilmemiş altı küçük oda ve dört dikme ile desteklenmiş geniş bir mekân bulunduğu fark edilmektedir. Bu geniş mekânın derslik olduğu düşünülmektedir. Manastıra ek olarak yapılacak birim içerisindeki 4 odanın da işlevi belirtilmemiş olup dışarıya açılan koridorlar bulunmaktadır. Her iki yapının duvar kalınlıklarından kâgir olarak yapıldığı, iç duvarlarının ise ahşap elemanlarla ayrıştırıldığı tahmin edilmektedir. (G. 9, G. 10).

48 B.O.A- İ.HR. 420/4-3 -H.05.07.1309 (4 Şubat 1892-mektep mülkü); B.O.A- İ.HR. 420/4-2-H.23.07.1309

(22 Şubat 1892- manastır mülkü)

49 B.O.A- İ.HR. 420/4-4-H.5.06.1315 (1 Kasım 1897-manstır mülkü)

50 B.O.A- İ.HR. 420/4-5-H.09.07.1323 (9 Eylül 1905- mektep mülkü)

51 B.O.A.I.HR.420.4.11. 


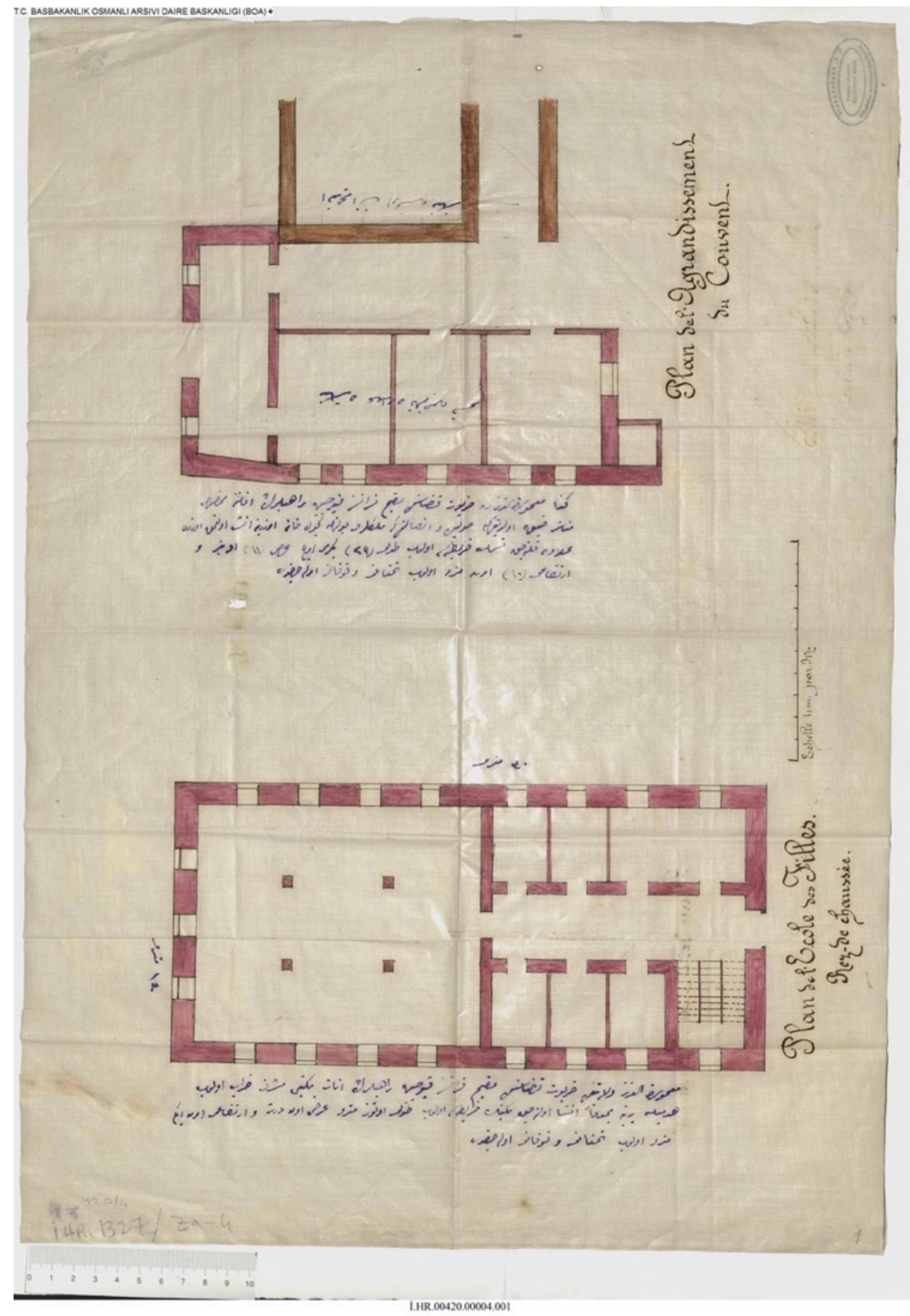

G. 9: Harput’taki Manastır ve Kilise Alanı, sağ Çizim Manastıra Ek Yapılacak Bölüm, sol Çizim Kız Mektebi (B.O.A. İ.HR.420.4.11) 


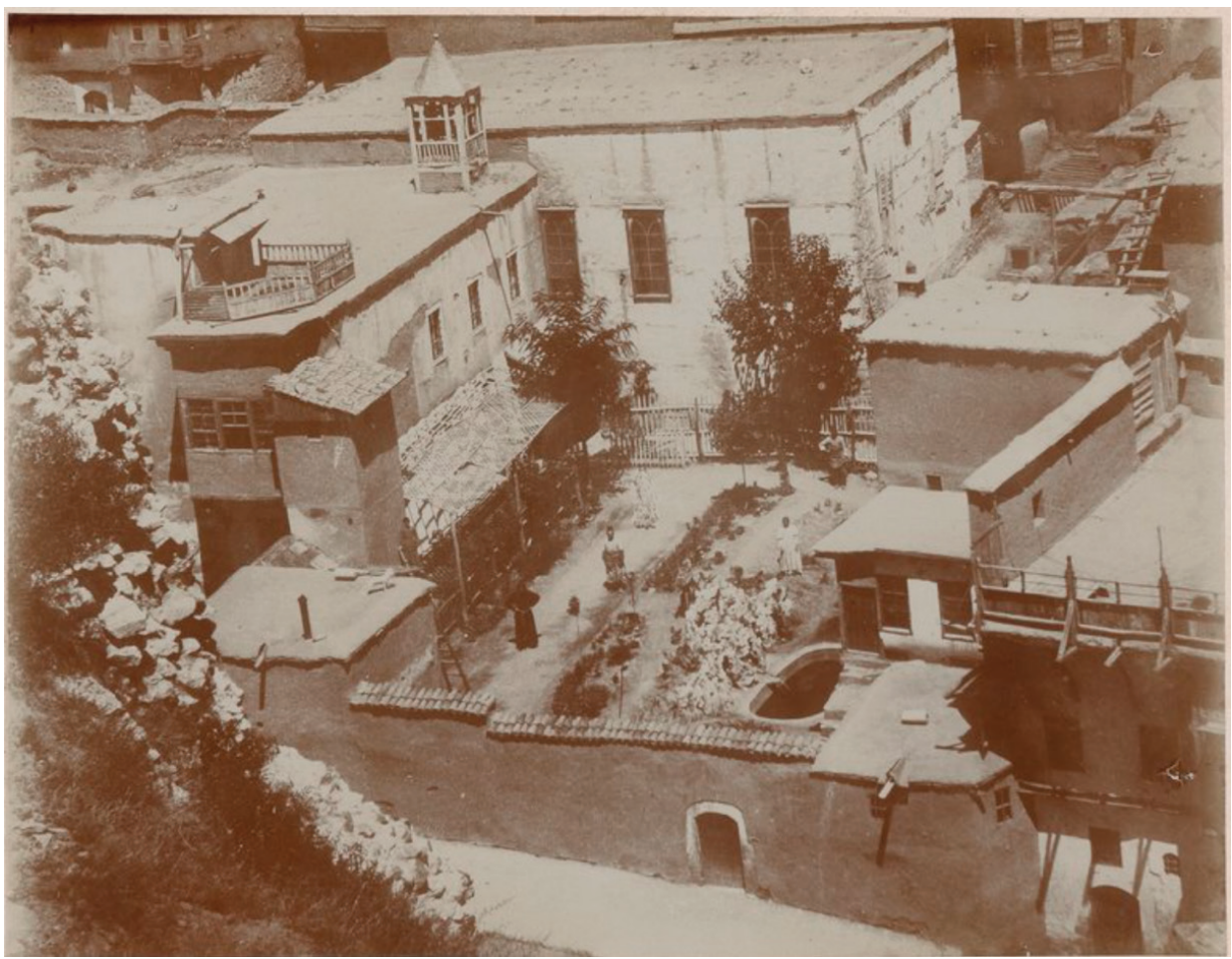

G. 10: Kapusen Rahiplerinin Harput'taki Manastır ve Kız Mektep Alanın Eski Hâli (Raphael, Albüm de la Mission de Mésopotamie er d'Arménie Confiée aux Fréres, Lyon, 3)

\section{Sonuç}

İncil'de geçen "Bible Land” Osmanlı hâkimiyeti altında olan Anadolu coğrafyası, misyon çalışmaları açısından ayrı bir öneme sahiptir. 15. yüzyıldan itibaren Katoliklerin misyonerlik faaliyetleri İstanbul'da başlamış, yüzyıllar içerisinde Anadolu'da etki sahaları genişlemiştir. Katolik misyonun İstanbul'da önemli bir halkası olan St. Louis Dil Okulu'nda eğitim gören rahipler, daha sonra Anadolu coğrafyasında faaliyet göstermişlerdir. Katolik misyonerliği genellikle Fransız himayesinde olup Anadolu'da (Diyarbakır ve Mardin) 1630'lardan beri Fransız Kapusenlere ait misyonerlik faaliyetleri sürdürülmüştür. Osmanlı topraklarında Hristiyan misyonerliğinin bir diğer kolu Protestanlık mezhebi altında yürütülmüştür. Bu çalışmalar Anadolu coğrafyasında 19. yüzyılın başlarından itibaren Britanya ve Amerika öncülüğü ile başlamış, daha sonra Alman misyonerlerin de katkısıyla devam etmiştir.

Mamuratü'l-Aziz ve Harput'taki misyon hareketleri (Katolik ve Protestan Misyonlar1), Osmanlı coğrafyasının genelinde olduğu gibi, 19. yüzyılın ikinci yarısında başlamıştır. Literatürde Harput'taki Protestan mezhebine bağlı American BOARD uhdesindeki faaliyetler kolayca takip edilebilmekte ancak Kapusen Katolik misyonu hakkında bilgi oldukça sınırlıdır. Kapusen Rahiplerinin Harput çevresinde (Diyarba- 
kır, Mardin) 17. yüzyıla kadar uzanan faaliyetleri hakkında veriler olmasına rağmen, Harput ve daha sonra Mamuratü'l-Aziz merkezinde ne zamandan beri aktif olarak çalıştıkları bilinememektedir. Harput'taki Fransız konsolosluğuna ait 19. yüzyılın ortalarına dayanan belgelerden yola çıkılarak bölgede etkin bir Fransız nüfusundan söz edilebilmekte, misyon faaliyetlerinin bu zaman aralığında başladığı varsayılmaktadır.

Fransız Kapusen Rahiplerinin inşa faaliyetlerinin önce Harput'ta mı yoksa Mamuratü'l-Aziz vilayet merkezinde mi başladığı tam olarak ayrıştırılamasa da Mamuratü'l-Aziz'de 1869'da Fransız Kolejinin varlığından bahsedilmektedir. Kolej hakkında en net bilgi 1916' da Maarif Nezaretine devir işlemi sonrasında ele alınmış 1/500 ve 1/200 ölçekte (mikyas) vaziyet ve kat planları çizimleri üzerinden edinilmektedir. Fransız Koleji, Maarif Nezaretine geçtikten sonra alanda bulunan üç yapıdan biri kız diğeri erkek mektebi olarak kullanılmıştır. Kolejin erkek mektebine dönüştürülen binasının ön cephesi yörede yaygın olarak kullanılan cumbalı ev formundadır. Kilise yapısının giriş bölümü üstünde yer alan çan kulesi ise gotik kilise kulelerinin tepe formlarına benzetilmiştir.

Mamuratü'l-Aziz vilayetindeki merkez yerleşimi dışında kalan bir diğer önemli şehir Harput'tur. Harput'taki Kapusenlere ait 20. yüzyılın başında alınmış tapu belgeleri olmasına rağmen, arazilerde bulunan yapıların daha önceden yapıldığı anlaşılmaktadır. 1903'te bir okul, daha sonra 1909'da yeni bir kız mektebi ve eski manastır yapısına ek yapılmasına dair çizimlerden, yapılaşmanın yeni olmadığı anlaşılmaktadır. 1903 'teki yapının iptidai mahiyette olan çizimlerinden iki katlı bir yapı inşa edileceği anlaşılmaktadır fakat ikinci kattın çizimleri belgede bulunmamaktadır. Normal kat planlarında bodruma inen merdivenler dışında başka bir merdiven görülmemekte, üst kat bağlantısı çizimler üzerinden anlaşılamamaktadır. Çizimlerde bodrum ve normal kat ile ön cephesi gösterilmiş olup duvar kalınlıkları ve pencere çizim tekniğinden dış duvarlarının taş malzemeden yapıldığı düşünülmektedir.

1909 yılına ait çizimlerde ise Harput'ta bulunan manastır arazisinde yeni bir kız mektebi ile manastıra ek yapı inşa edilmesi istenmektedir. Fakat çizimlerde sadece kat planları olduğundan iç mekânların işlevleri tam olarak anlaşılamamaktadır. Kız mektebine ait çizimlerdeki mekân hiyerarşisi göz önüne alındığında bir ana derslik ve altı küçük birim bulunduğu düşünülebilir. Bölgedeki yapı stokunun kerpiç olduğu göz önüne alındığında, Kapusenlerin Mamuratü'l-Aziz ve Harput'taki yapılaşmasında, kalıcı ve ayrıcalıklı bir yaklaşım kaygısı içerinde oldukları düşünülmektedir. Bu yapılardan hiçbiri günümüze ulaşmamış olup en uzun süre ayakta kalmış olan Fransız Koleji (Eski Muallim Mektebi) 1950’lerin ortasında yanmıştır. 
Hakem Değerlendirmesi: Dış bağımsız.

Çıkar Çatışması: Yazar çıkar çatışması bildirmemiştir.

Finansal Destek: Yazar bu çalışma için finansal destek almadığını beyan etmiştir.

Peer-review: Externally peer-reviewed.

Conflict of Interest: The author has no conflict of interest to declare.

Grant Support: The author declared that this study has received no financial support.

\section{Kaynakça/References}

Açıkses, Erdal. Amerikalıların Harput'taki Misyonerlik Faaliyetleri. Ankara: Türk Tarih Kurumu Basımevi, 2003.

Aksın, Ahmet. 19. Yüzyılda Harput. Elazığ: Ceren Ofset ve Matbaacılık \& Reklamcılık, 1999.

Aksoy, Ekrem. "Başlangıcından Günümüze Türkiye'de Fransız Okulları". Synergies Turquie 8 (2015): 29-46.

Akyel, Salih. “19. Yüzyılın İlk Yarısında Harput Şehrinin Nüfus ve Toplum Yapısı”. Doktora Tezi, Frrat Üniversitesi, 2013.

Alan, Gülbadi. Osmanlı Imparatorluğu'nda Amerikan Protestan Okulları. Ankara: Türk Tarih Kurumu Yayınları, 2015.

"Ambassade de France à Constantinople", Bibliothèque Nationale de France, 1722. Erişim 20 Aralık 2020, https://gallica.bnf.fr/ark:/12148/btv1b53043303z?rk=429186;4.

Ardıçoğlu, Nureddin. Harput Tarihi. Ankara: Yükseköğretim Kurulu, 1997.

Aydın, Mehmet. “Türkiye’ye Yönelik Katolik Misyonerliğin Dünü ve Bugünü”. Türkiye'de Misyonerlik Faaliyetleri. İstanbul: İslami İlimler Araştırma Vakfı, 2004, 93-122.

Aytaç, İsmail. "Malatya-Harput Kervan Yolu Güzergahı ve Kervansarayı”. Dünü ve Bugünüyle Harput: Sempozyumu: Tarih, Edebiyat, Şiir, Folklor. Elazığ: Türkiye Diyanet Vakfı Elazığ Şubesi Yayınlar1, 225-47.

Birsel, Haktan. "Fransız Misyonerler Tarafindan İstanbul ve Levant Misyonun Oluşturulması (Papaz J. Paptist Piolet'nin Mektubu)". Turkish Studies 9/4 (2014): 207-223.

Bozan, Oktay. ' Osmanlı Döneminde Amerikan Misyonerlerinin Diyarbakır Vilayetine Gelişi ve Faaliyetleri”, Dicle Üniversitesi Sosyal Bilimler Enstitüsü Dergisi 13 (2015): 333-361.

(B.O.A.)I.HR.420.4.11.

Çoban, Mehmet. "Bir Katolik Cemaati Olarak Fransiskenler”. Yüksek Lisans Tezi, Marmara Üniversitesi, 2008.

Danık, Ertuğrul, “Orta Çağ Harput’un Kentsel Gelişimi”, Dünü ve Bugünüyle Harput: Sempozyumu: Tarih, Edebiyat, Şiir, Folklor, Elazı̆̆: Türkiye Diyanet Vakfi Elazı̆̆ Şubesi, 1999, 71-73.

Gündüz, Şinasi. "Misyonerlik". Türkiye Diyanet Vakfi İslam Ansiklopedisi. C. 30. İstanbul: Türkiye Diyanet Vakfi Yayınları, 2005, 193-99.

“1914 tarihli harita.”Erişim 29Aralık 2021, https://archives.saltresearch.org/handle/123456789/102338,

Haydaroğlu, İlknur Polat. Osmanlı İmparatorluğu'nda Yabancı Okullar. Ankara: Kültür Bakanlığ Yayınları, 1990.

İnan, Uğur. Osmanlı Devleti’nde Almanların Protestan Misyonerlik Faaliyetleri. Ankara: Türk Tarih Kurumu Yayınları, 2015. 
Mutlu, Şamil. “Osmanlı İmparatorluğunda Yabancı Okullar”. Doktora tezi, İstanbul Üniversitesi, 1999.

Özcan, Tuğrul. Merkezî ve Modern Eğitim Kapsamında Osmanlı Gayrimüslim Cemaat ve Yabancı Okulları. İstanbul: Gece Kitaplığı, 2017.

Raphael, Frére. Albüm de la Mission de Mésopotamie er d'Arménie Confiée aux Fréres- Mineurs Capucins de la Provinee de Lyon, 1904.

Sağ, Mustafa Kaan. “Osmanlı Başkenti İstanbul'da Britanya Kökenli Misyoner Okulları ve İskoç Bir Yapı Ustası: Nicholson Burness”. Doktora Tezi, İstanbul Teknik Üniversitesi, 2017.

Taş, Tülin. “19. Yüzyıl Anadolu'da Katolik Misyonerlerin Eğitim Alanındaki Faaliyetleri”. Yüksek Lisans Tezi, Erciyes Üniversitesi, 2006.

Taşkın, Ünal. "Maarif Salnamelerinde Mamuratülaziz". International Journal of Social Science 6 (2013): 1327-1353.

Ünal, Mehmet Ali. XVI. Yüzyılda Harput Sancağı (1518-1566). Ankara: Türk Tarih Kurumu Basımevi, 1989.

Yorulmaz, Şerife. "Osmanlı Fransız İlişkileri Çerçevesinde Osmanlı Topraklarında Açılan Fransız Kültür Kurumları ve Bunların Meşruiyet Kazanması (19.yy-20.yy başları)”. Ankara Üniversitesi OTAM Dergisi 11 (2000): 697-768.

Yücel, İdris. Anadolu'da Amerikan Misyonerliği ve Misyon Hastanesi. Ankara: Türk Tarih Kurumu, 2017. 
